\title{
Biographical Notes on Contributors
}

Gloria J. Berk is presently a psychotherapist in private practice. Mrs. Berk received a master's degree from the Smith College School for Social Work. Before joining the staff of the Payne Whitney Adolescent Psychiatric Out-Patient Clinic of the New York Hospital, she participated in the work of the Bureau of Mental Hygiene in Hartford, Connecticut, and the Co-ordinated Community Mental Health Clinics of Brooklyn.

Charles C. Hughes, Professor of Anthropology and Director of the African Studies Center at Michigan State University, received his Ph.D. degree in anthropology from Cornell University. Dr. Hughes has been a Fellow at the Center for Advanced Study in the Behavioral Sciences and has done field research in Nova Scotia, Alaska, Liberia, and Nigeria. His publications include An Eskimo Village in the Modern World (Cornell University Press, 1960) and co-authorship of People of Cove and Woodlot (Basic Books, 1960) and Psychiatric Disorder among the Yoruba (Cornell University Press, 1963). He has published articles on Eskimo culture, cultural change and social psychiatry in such journals as the American Antbropologist, Current Antbropology, and the Journal of Social Issues.

Thomas S. Langner, Assistant Professor of Psychiatry (Sociology) at the New York University School of Medicine, 
received his Ph.D. in sociology from Columbia University. Dr. Langner has done anthropological research in Mexico and the American Southwest; race relations research for the AntiDefamation League; propaganda analysis for the Voice of America, and studies of the aged. He is currently engaged in a program of interdisciplinary research at New York University, Department of Psychiatry. His publications include contributions to many scholarly journals as well as co-authorship of Five Hundred Orer Sixty (Russell Sage, 1956), Mental Health in the Metropolis (McGraw-Hill, 1962), and Life Stress and Mental Health (The Free Press of Glencoe, 1963).

Alexander H. Leightox, Director of the Cornell Program in Social Psychiatry, is Professor of Psychiatry (Social Psychiatry) at the Cornell University Medical College and Professor of Sociology and Professor of Anthropology at the College of Arts and Sciences, Cornell University. Dr. Leighton received his medical degree from Johns Hopkins Medical School. He has been a Fellow at the Center for Advanced Study in the Behavioral Sciences and the holder of a Reflective Fellowship from the Carnegie Corporation of New York. His publications include The Governing of Men (Princeton University Press, I945), Human Relations in a Changing World (E. P. Dutton, 1949), My Name Is Legion (Basic Books, 1959), An Introduction to Social Psychiatry (Charles C. Thomas, i96o), and coauthorship of People of Cove and Woodlot (Basic Books, 1960), The Character of Danger (Basic Books, 1963), and Psychiatric Disorder among the Yoruba (Cornell University Press, 1963).

Dorothea C. Leightox is Clinical Associate Professor of Psychiatry (Social Psychiatry) at the Cornell University Medical College and Senior Research Associate and Lecturer in the Department of Sociology and in the Department of Anthropology of the College of Arts and Sciences, Cornell University. Dr. Leighton received her medical degree from Johns Hopkins Medical School and has done field research among the Navaho, Zuñi, 
St. Lawrence Eskimos, and Yoruba. She has been doing epidemiological research in the Stirling County Study, now a part of the Cornell Program in Social Psychiatry. Her publications include co-authorship of The Navaho Door (Harvard University Press, 1944), The Navaho (Harvard University Press, 1946), Children of the People (Harvard University Press, 1947), The Character of Danger (Basic Books, 1963), and Psycbiatric Disorder among the Yoruba (Cornell University Press, 1963).

Edward Llewellyn Thomas is Associate Professor of Pharmacology at the University of Toronto and Medical Research Associate at Ontario Hospital, New Toronto. He received his medical training at McGill University. Before the war, he trained as an engineer at the University of London and is at present carrying on his research at the Institute of Bio-medical Electronics, a joint project between the Faculty of Medicine and the Faculty of Engineering at the University of Toronto. Dr. Thomas is also a part-time Professor of Psychology at the University of Waterloo, where he has been teaching a course in $\mathrm{Hu}-$ man Factors Engineering in Canada. He has contributed articles to Science, Canadian Medical Association Journal, Canadian Psychiatric Association Journal, Radiology, Canadian Journal of Psychology, Journal of Aerospace Medicine, and the Journal of Projective Techniques.

James F. Masterson, Clinical Associate Professor of Psychiatry at the Cornell University Medical College, is Director of the Research Project on Psychiatric Disorder in Adolescents and is in charge of the Adolescent Division of the Payne Whitney Out-Patient Department. Dr. Masterson received his medical degree from Jefferson Medical College and combines his research interests with part-time practice in psychiatry. He has contributed to journals such as Psychiatry, Journal of Nervous and Mental Disease, American Journal of Psychiatry, and The Medical Clinics of North America. 
Jane M. Murphy is Assistant Professor of Anthropology in the Department of Psychiatry of the Cornell University Medical College and Research Associate in the Department of Sociology and in the Department of Anthropology, College of Arts and Sciences in Cornell University. Dr. Murphy received her Ph.D. degree in anthropology from Cornell University and has done field work in Alaska, Nova Scotia, and Nigeria. She contributed to the research of the Stirling County Study and is currently with the Cornell Program in Social Psychiatry. Her publications include collaboration on An Eskimo Village in the Modern World (Cornell University Press, 1960), coauthorship of Psycbiatric Disorder among the Yoruba (Cornell University Press, 1963), and articles on cross-cultural psychiatry and psychotherapy in World Mental Health, the Milbank Memorial Fund Quarterly, and Magic, Faith, and Healing, edited by Ari Kiev (The Free Press at Glencoe, 1964).

Seymour Parker, Associate Professor of Anthropology and Associate Professor of Social Science at Michigan State University, was formerly a cultural anthropologist in the Department of Psychiatry of the Jefferson Medical College. He received his Ph.D. degree in anthropology from Cornell University, and his field work includes research in Nova Scotia, New Mexico, and Alaska. He has also participated in studying the social structure of a mental hospital in England, and is currently working on a study of mental health among Negroes in Philadelphia. Dr. Parker has contributed to many journals such as the American Antbropologist, American Sociological Review, Psycbiatry, Etbnology, and Human Relations.

Tom T. SASAKI is Associate Professor in the Department of Sociology, University of New Mexico. His Ph.D. degree in sociology was received from Cornell University. He has done field work among the Navaho and the Jicarilla Apache and has served as a social science consultant to the Navaho Indian 
Tribe as well as to various training and extension programs in the American Southwest. Dr. Sasaki was formerly Field Director of the Cornell-Navaho Project in Technological Change. $\mathrm{He}$ is the author of Fruitland, New Mexico: A Navabo Community in Transition (Cornell University Press, 1960) and has published articles about the American Indians in the American Antbropologist, Journal of Social Issues, Rural Sociology, New Mexico Business, and other journals.

Charles Savage is Director of Research, Spring Grove State Hospital, Baltimore, Maryland. Dr. Savage received his medical degree from the University of Chicago and is a graduate of the Washington School of Psychiatry and a member of the American Psychoanalytic Association. He has been a Fellow at the Center for Advanced Study in the Behavioral Sciences; earlier he was Acting Chief of the Adult Psychiatric Branch of the National Institute of Mental Health. He has had field experience among the Navahos in New Mexico and the Yoruba of Nigeria and has contributed papers to numerous journals such as American Journal of Psychiatry, Journal of Nervous and Mental Disease, Archives of Psychiatry and Neurology, Psychoanalytic Review, Diseases of the Nervous System, and Psychiatry.

Marie-Louise Schoelly is Clinical Assistant Professor of Psychiatry in the Division of Child Psychiatry of the Cornell University Medical College. She received her medical education at the University of Zurich, Switzerland, and took her psychiatric residency at the Psychiatric University Clinic in Basel, Switzerland. She is currently engaged in research concerning psychiatric symptoms in childhood and also practices psychiatry in New York City. Dr. Schoelly has written on the use of curare in electroshock therapy and on psychosis associated with tetany in such journals as the Journal of American Physical Medicine and the Monthly Review of Psychiatry and Neurology. 
Albert C. Sherwix is Clinical Associate Professor of Psychiatry in the Department of Psychiatry and Director of the Division of Child Psychiatry in the Cornell University Medical College. He received his medical degree from Columbia University Medical College of Physicians and Surgeons. In addition to a part-time practice, Dr. Sherwin is doing research on childhood symptoms. He has published articles on the relationship between psychopathology and music as well as papers on various psychiatric disorders found in children in journals such as the American Journal of Psychiatry, Journal of Nervous and Mental Disease, Bulletin of the New York Academy of Medicine, and the Journal of Chronic Diseases.

Kenneth F. Tucker, who received his medical degree from Cornell University Medical College, is a Clinical Instructor in Psychiatry at that institution. Currently he devotes the major part of his time to the private practice of psychiatry. He has participated in the research on adolescence conducted at the Payne Whitney Clinic. He has contributed to the American Journal of Psychiatry. 